Article

\title{
Technopreneurial Intentions among Bulgarian STEM Students: The Role of University
}

\author{
Desislava Yordanova ${ }^{1}\left[\right.$, José António Filipe ${ }^{2, * \mathbb{C}}$ and Manuel Pacheco Coelho ${ }^{3(\mathbb{C}}$ \\ 1 Faculty of Economics and Business Administration, Sofia University “St. Kliment Ohridski”, \\ 125 Tzarigradsko Shosse Blvd., blok 3, 1113 Sofia, Bulgaria; d_yordanova@feb.uni-sofia.bg \\ 2 Departamento de Matemática, ISTA-Escola de Tecnologias e Arquitectura, Iscte-Instituto Universitário de \\ Lisboa, Information Sciences, Technologies and Architecture Research Center (ISTAR-IUL), \\ Business Research Unit-IUL (BRU-IUL), 1649-026 Lisbon, Portugal \\ 3 SOCIUS, ISEG/University of Lisbon, 1649-004 Lisboa, Portugal; coelho@iseg.ulisboa.pt \\ * Correspondence: jose.filipe@iscte-iul.pt
}

Received: 3 July 2020; Accepted: 5 August 2020; Published: 11 August 2020

check for updates

\begin{abstract}
Entrepreneurship, innovation and technology are essential to the economic development of societies. Universities are increasingly involved in creating an internal favourable environment supporting entrepreneurship and innovation. In our work, we aimed to study the role of university for the development of technopreneurial intentions in a sample of Bulgarian STEM (STEM refers to any subjects that fall under the disciplines of science, technology, engineering or mathematics.) students exhibiting entrepreneurial intentions. The empirical findings of the study are in line with previous empirical evidence about the role of university support for entrepreneurial intentions among students; results also show that students in universities with better research in their scientific field of study are more likely to exhibit technopreneurial intention. Determinants of entrepreneurial intentions identified in the literature such as entrepreneurial role models, perceived support from social networks, willingness to take risks and gender may not be relevant specifically for technopreneurial intentions. The results of the study have important practical implications.
\end{abstract}

Keywords: entrepreneurship; innovation; ecosystem; technopreneurial intentions

\section{Introduction}

The bodies of literature on innovation ecosystems and entrepreneurship ecosystems acknowledge the important role of universities in the development of human capital, knowledge capital and entrepreneurship capital [1]. Markkula and Kune [2] argued that universities may cultivate the spirit of entrepreneurial discovery which drives innovation in regional innovation ecosystems. Researchers, students and companies may discover new opportunities and ideas, experiment, and take risks for the purpose of creating value [2]. Although the research on the role of university for entrepreneurship development has focused predominantly on patent-based activities, technology transfer, and scientific research by academic staff, empirical evidence suggests that students may be as twice as likely as faculty members to start a new venture after graduation and that the ventures founded by recent graduates are not of low quality [3]. The role of entrepreneurship education for fostering entrepreneurial intentions among students is a relatively well-researched topic. A large body of literature on entrepreneurship education demonstrates that entrepreneurial intentions and behaviour among students are positively associated with entrepreneurship education [4-6]. Entrepreneurship among students and recent alumni is also influenced by the university context and there is a need for greater understanding of the nature and determinants of student entrepreneurial systems [7]. 
Technology entrepreneurship emerges between two major scientific fields: entrepreneurship and technology-based innovation [8], and therefore may play a vital role in enhancing sustainable development. It was acknowledged that entrepreneurship may contribute in diverse ways to the economic, social and environmental dimensions of sustainable development [9-11]. Entrepreneurship and innovation can provide solutions to pressing economic, social and environmental problems [12,13]. Countries with strong performance in terms of innovative entrepreneurship are placed in the top of the rankings for sustainable development, while countries with weaker performance on this indicator have lower scores of sustainable development [13]. In the United Nations plan of actions "The 2030 Agenda for Sustainable Development," entrepreneurship and innovation are expected to contribute to achieving many of the established sustainable development goals and targets including promoting employment and economic growth, developing and diffusing environmentally sustainable technologies, increasing of capacity-building for developing countries, enhancing technology capabilities in different sectors, etc. [12].

Academic research in technology entrepreneurship has generated a complex and interdisciplinary literature which relies on diverse theoretical backgrounds and addresses a wide number of topics [14]. Several important research gaps in this literature have been identified. Shane and Venkataraman [15] highlighted the need for more research on the context for technology entrepreneurship, the process of new technology venture creation and the drivers to create new technology ventures. Mosey, Guerrero and Greenman [16] called for more research exploring the role of various university support measures including entrepreneurship education for the generation of talent and the experience of individuals in relation to technology entrepreneurship. Mosey [17] suggested that universities are an ideal research setting for investigating technology entrepreneurship.

Technology entrepreneurship is viewed as a specific type of entrepreneurship that is essentially different from other types of entrepreneurship such as social entrepreneurship, small business management and self-employment [18]. Lee and Wong [19] demonstrated that scientists and engineers exhibit different entrepreneurial intentions in relation to the type of business they intend to start. However, the available research on entrepreneurial intentions has regarded this construct as largely homogeneous [20]. Liñán and Fayolle [21] identified 409 papers researching entrepreneurial intentions between 2004 and 2013, but only 18 papers address specific types of intentions. Fayolle and Liñán [22] emphasized the need to investigate various entrepreneurial scenarios related to this construct. Given these gaps, the research objective of the present study was to identify university-level and individual-level factors related to the university, which are associated with the likelihood of technopreneurial intentions in a sample of 337 Bulgarian STEM (science, technology, engineering or mathematics) students exhibiting entrepreneurial intentions controlling for other individual-level factors.

The paper is structured as follows. Section 2 contains a review of the literature on technology entrepreneurship and entrepreneurial intentions and hypotheses about the role of university-related factors for the likelihood of technopreneurial intentions among STEM students. Section 3 describes the research methodology adopted in the study. Next, the empirical findings of the study are presented in Section 4. Lastly, Section 5 provides discussion, conclusions, limitations, practical implications and recommendations for future research.

\section{Background, Conceptual Model and Hypotheses}

\subsection{Technology Entrepreneurship: At the Crossroad of Entrepreneurship and Technology-Based Innovation}

Technology entrepreneurship is receiving increasing attention among academics, policy makers, entrepreneurs, managers and investors since the first symposium on technology entrepreneurship at Purdue University (USA) in 1970 [18]. During the past decades, academic research in the field of technology entrepreneurship has progressed rapidly in terms of volume, breadth and diversity [14,18], but there is still no consensus among academics about the definition of 
this concept. Burgelman, Christensen and Wheelwright [23] (p. 3) argued that technological entrepreneurship involves "activities that create new resource combinations to make innovation possible, bringing together the technical and commercial worlds in a profitable way." It includes "exploiting opportunities, and assembling resources around a technological solution" [14] (p. 2) and "the transformation of promising technologies into value" [24] (p. 9). Petti [25] adopted a systemic view of technology entrepreneurship, positing that in, addition to entrepreneurial and managerial components, technology entrepreneurship involves also an environmental component. Technological opportunities emerge and are exploited in a system of interactive actors engaged in various activities related to the development and identification of technologies, recognition of opportunities, product development and business development and creation [20,21]. The environmental component consists of external institutions, relational configurations and resources that condition the development of technology entrepreneurship [24,25]. Garud and Karnøe [26] conceptualized technology entrepreneurship as a distributed agency involving not only technology entrepreneurs themselves but also customers, actors who develop complementary assets and those in institutional forums. The authors emphasized that all these actors may actively participate in the entrepreneurial process to shape the emerging technology in different ways.

Hsu [27] emphasized that technology entrepreneurship, by its nature, is innovation-based. Technology entrepreneurship may be distinguished from mainstream entrepreneurship, because it is concerned with new opportunities stemming particularly from innovation in science, and engineering $[8,25]$ (p. XIII) views technology entrepreneurship as a process incorporating four main sets of activities: the creation or identification of technologies; recognition of opportunities; technology development/application; and creation of a business that utilizes the technology/application developed to generate value. ([18], p. 9) emphasizes that technology entrepreneurship is not about small businesses or general management practices in such businesses owned by engineers or scientists. It is about creating and capturing value through producing and adopting technology ([18], p. 9).

Technology entrepreneurship involves various outcomes including value creation [18,24], value capture [18], creation of new resource combinations [23], creation of new technology-based firms [28-30], creation of (new/innovative) products, services or processes [31,32].

As a research field, technology entrepreneurship involves different levels of analysis including individual level, product/service, business/firm, and the system as a whole [23,31,33]. Burgelman, Christensen and Wheelwright [23] (p. 3) distinguished between individual technology entrepreneurship and corporate technology entrepreneurship. Phan and Foo [33] (p. 2) outlined several levels of analysis: individual level, (scientists/entrepreneurs, venture capitalists and other individuals with contribution to technology entrepreneurship); organizational level (technological teams, structures, processes and interorganizational linkages influencing value creation); and systems level (players in the ecology of value creation including governing factors, industry standards and the economics of geographical locations). Spiegel and Marxt [31] also identified three levels of analysis related to product/service, business/firm and the system as a whole and distinguished between new entrants and existing firms. They argued that both new technology-based firms and incumbent technology-based firms play a significant role for the commercialization of new technologies, but different issues in technology entrepreneurship may receive a different focus in new and existing technology-based firms [31].

A number of differentiating aspects of technology entrepreneurship relative to economics, entrepreneurship and management have been identified [18] (p. 10):

i. the interdependence between scientific and technological change and the selection and development of new products, assets and their attributes;

ii. the application of technology entrepreneurship to both new and established firms as well as to both small and large firms;

iii. conceptualization of technology entrepreneurship as an investment in a project; 
iv. the interdependence between technology entrepreneurship and the resource-based view of sustainable competitive advantage;

v. the interdependence between technology entrepreneurship and the theory of the firm.

As a relatively under-researched topic, technology entrepreneurship is seen as a promising area for entrepreneurship research and practice [34].

\subsection{Entrepreneurial Intentions and Their Antecedents}

It was recognized by researchers in entrepreneurship that new venture formation is a planned behaviour, an intentional act which requires planning how the perceived opportunity will be exploited [35-39]. Since entrepreneurship could be treated as planned behaviour, models of intentions and their antecedents are a useful framework for studying entrepreneurial behaviour [36]. The emphasis on intentions is especially valuable when investigating phenomena that are rare, hard to observe and involving unpredictable time lags such as entrepreneurship [40]. "Thus, a strong intention to start a business should result in an eventual attempt, even if immediate circumstances such as marriage, child bearing, finishing school, a lucrative or rewarding job or earthquakes may dictate a long delay" ([36], p. 414). In this case, entrepreneurial intentions provide understanding about entrepreneurial behaviour without witnessing that behaviour [37].

Intentions-based models allow us to better understand why individuals made certain decisions in the process of new venture creation and to predict entrepreneurial behaviour [36]. Entrepreneurial intentions play a mediating role between potential exogenous antecedents such as demographics, traits, perceived availability of critical resources and situational role beliefs and the act of new venture formation [36]. The dominant models in the research on entrepreneurial intentions are Bird's model [35] for implementing entrepreneurial ideas; Shapero and Sokol's model [41] of the entrepreneurial event; and Ajzen's [42] theory of planned behaviour, and only the last two models have received empirical support in the literature [22].

Shapero and Sokol's model [41] of the entrepreneurial event was developed specifically for the domain of entrepreneurship [36]. For [41] (p. 72), there is an association between the entrepreneurial event and "initiative-taking, consolidation of resources, management, relative autonomy, and risk-taking." These authors suggested that an entrepreneurial event is affected by the social and the cultural environment and several other social factors. Shapero and Sokol's model [41] of the entrepreneurial event reveals how cultural and social variables influence entrepreneurial behaviour [43]. In this model, entrepreneurial intentions are derived from three attitudinal variables: perceived desirability, perceived feasibility and a propensity to act upon opportunities [36]. Perceived desirability is defined as the perceived attractiveness of starting a business, while perceived feasibility is the degree to which a person feels capable of starting a business [36]. Krueger, Reilly and Carsrud [36] commented that the Theory of Planned Behaviour (TPB) and the Shapero and Sokol's model overlap considerably with regard to several elements. Moreover, the models explain similar proportions in the variation of intentions [32].

Attitudinal antecedents of entrepreneurial intentions posited by the TPB and other similar theoretical models have received empirical support. Attitudinal constructs have statistically significant influence on entrepreneurial intentions [36,44-47]. Individuals with close entrepreneurial role models are more likely to exhibit entrepreneurial intentions [43,48,49]. Preferences, perceptions, other cognitive factors and psychological traits tend to be linked to entrepreneurial intentions $[44,48,49]$.

\subsection{University as an Entrepreneurship and Innovation Ecosystem}

The mission and academic tasks of the university have changed profoundly as a result of two academic revolutions [50]. The first academic revolution led to the adoption of research as another university function in addition to the traditional academic task of teaching, while the second academic revolution added a new academic task related to economic and social development. Graham [51] (p. 1) emphasized that governments "are looking to technological innovation as a driver 
for national grown and to universities as the incubators of this national capacity." The emergence of the entrepreneurial university is a response to the increasing importance of knowledge in national and regional innovation systems [52]. Universities are increasingly involved in creating an internal favourable environment supporting entrepreneurship and innovation. Entrepreneurial and innovation activities within universities are supported by various support mechanisms, activities, structures, and intermediaries such as technology transfer offices, accelerators, incubators or science parks, etc. [7,53,54]. An entrepreneurial ecosystem for student entrepreneurship within university involves a continuum of activities (early-stage support, accelerators and incubators), variety of entrepreneurs (alumni, students, faculty, post-docs), support actors (internal and external actors) and investors [7]. In addition to direct mechanisms for supporting the transfer of technology from academia to industry, there are also indirect mechanisms supporting entrepreneurial activities via entrepreneurship education [55].

Drawing upon the growing literature about the role of university for the development of entrepreneurship and innovation, the conceptual model adopted in this study (Figure 1) suggests that the development of technopreneurial intentions among STEM students is influenced by the participation in entrepreneurship education, university support with concept and business development and university research excellence. The construct technopreneurial intentions indicates if the respondent thinks s/he will start a technology business [38]. Kraaijenbrink, Bos and Groen [56] differentiated among various types of university support. University support with concept development refers to increasing students' awareness and motivation and providing students with ideas and knowledge needed to start a new business. University support with business development refers to support to start-ups such as provision of financial means. University support with concept development is provided to students in the early stages of the entrepreneurial process, while university support with business development is oriented to start-ups in the later stages of the entrepreneurial process. The construct participation in entrepreneurship education refers to participation in both compulsory and elective entrepreneurship courses. The construct university research excellence refers to the research productivity of university based on its publication and citation records.

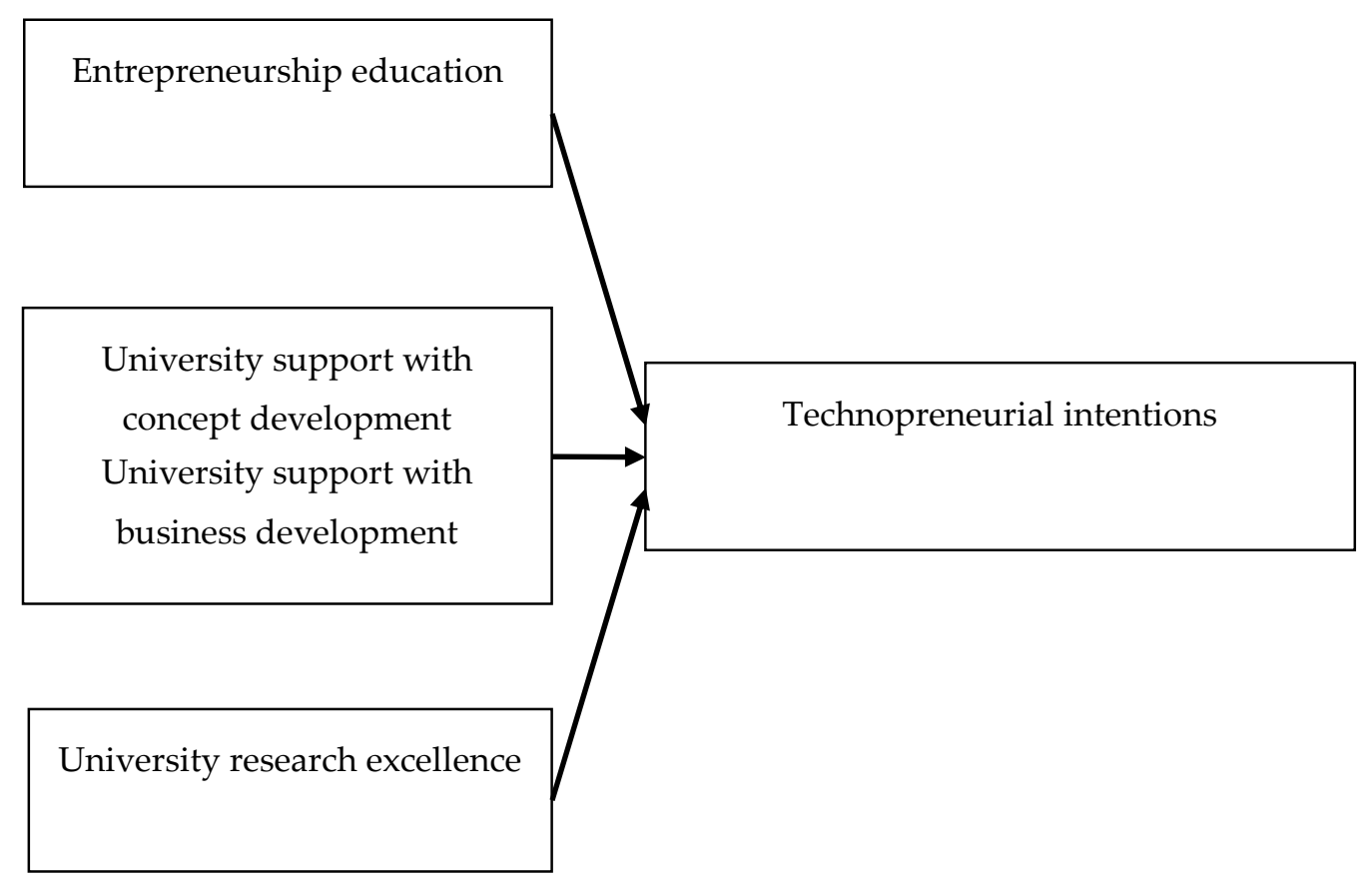

Figure 1. Conceptual model of the role of university for students' technopreneurial intentions.

The research on entrepreneurship education reveals that entrepreneurship education enhances entrepreneurship knowledge and skills, intentions and behaviour. Johannisson [57] suggested that learning from entrepreneurship education occurs at different levels: $1 /$ know-why: values, 
attitudes, motivation; 2/know-what: knowledge; 3/know-how: abilities and skills; 4/know-when: experience and intuition; 5/know-who: social skills, networks. Falkäng and Alberti [58] identified several positive effects for participants in entrepreneurship education including self-employment and ability to act as an independent operator of a venture; personal and career satisfaction; knowledge and understanding acquisition; skills acquisition; identification of individual potential; changed attitudes. Knowledge is an important antecedent of opportunity identification related to technological change [59]. Martin et al. [4] undertook a quantitative review of the literature and found a significant positive relationship between entrepreneurship education and training and positive perceptions of entrepreneurship, entrepreneurship knowledge and skills, and entrepreneurial intentions. Hahn et al. [60] found that both elective and compulsory entrepreneurship education is conductive for the development of entrepreneurial skills. Rideout and Gray [61] reviewed the empirical research on the outcomes of university-based entrepreneurship education and confirmed the association between entrepreneurship education and psychological outcomes and significant effects of entrepreneurship education on entrepreneurial intentions and behaviour. Dickson et al.'s [5] review of the research on entrepreneurship education published between 1995 and 2006 demonstrated that entrepreneurship education positively influences entrepreneurial intentions. Bae et al. [62] showed that the correlation between entrepreneurship education and entrepreneurial intentions is greater than the correlation between business education and entrepreneurial intentions. Souitaris, Zerbinati and Al-Laham [47] illustrated that entrepreneurship education provides inspiration that raises entrepreneurial attitudes and intentions among STEM students. Technopreneurial learning has a positive impact on the technopreneurial intentions of students [63]. Therefore, we suggest that the participation in entrepreneurship education may lead to the development of technopreneurial intentions instead of other entrepreneurial intentions among STEM students:

Hypothesis 1 (H1). Participation in entrepreneurship education increases the likelihood of technopreneurial intentions among STEM students.

The university environment may stimulate and support entrepreneurial intentions and behaviour of students in various ways. The university environment and support for entrepreneurship may positively influence students' perceptions, attitudes and awareness about entrepreneurship as a career option and may encourage them to choose an entrepreneurial career [64]. It can also enhance students' motivation and self-confidence needed for an entrepreneurial career [65]. University may provide access to crucial start-up resources including experts, finance, contacts, know-how, counselling, etc., necessary for exploring entrepreneurial opportunities [64,65]. Concept development support may raise students' awareness of entrepreneurial opportunities, and thus may motivate them and increase their entrepreneurial self-efficacy [66]. Concept development support and business development support play significant roles for students' entrepreneurial self-efficacy and students' entrepreneurial intentions [56,65-67]. University entrepreneurial support is associated with students' entrepreneurship engagement [68].

STEM students exhibit certain characteristics such as aversion to financial and bureaucracy issues, lack of knowledge in the management field, lack of market focus and encounter certain obstacles related to lack of entrepreneurial skills, lack of skills for start-up development, and lack of financial resources for new product development and registering a patent [69]. Therefore, STEM students seek support from universities, entrepreneurship centres and incubators to overcome these specific obstacles [69]. University support factors positively affect the entrepreneurial intentions of technical students [44] and the creation of technology spin-offs versus nontechnology spin-offs [70]. Therefore, we suggest that the presence of concept development support and business development support within the university may help STEM students to develop technopreneurial intentions:

Hypothesis 2 (H2). University support with concept development increases the likelihood of technopreneurial intentions among STEM students. 
Hypothesis 3 (H3). University support with business development increases the likelihood of technopreneurial intentions among STEM students.

Technological advances based on scientific research represent an important source of technological opportunities [71]. Intellectual eminence of the university is an important factor that increases new firm formation [72]. Universities with higher levels of research productivity tend to develop higher entrepreneurial activity [73]. Rasmussen et al. [74] stressed that the extent of entrepreneurial activity and the types of the established new ventures are affected by university-level factors. Shane [59] discovered that the recognition of business opportunities stemming from technological innovations is determined by prior education and experience. Research-intense universities are a source of knowledge spillovers, creating entrepreneurial opportunities for exploiting new knowledge by starting high-tech firms [75-79]. Research institutions are an important source of knowledge for exploring new business opportunities among younger and well-educated founders of high-tech firms [80]. Technological knowledge from universities has a significant role also for the growth of academic spin-offs [81]. By fulfilling their educational function, academic institutions are transferring new knowledge to their students [77], who may exploit it for starting new high-tech ventures. Bonaccorsi et al. [82] found that the creation of knowledge-intensive firms is positively affected by new knowledge generated by high-quality universities, while low-quality universities have little effect on knowledge-intensive entrepreneurship. Research excellence has a significant positive impact on the discovery of technological opportunities [71]. Beyhan and Findik [83] reported that research excellence of the university is associated with the odds of new technology venture creation among students and new graduates. They concluded that high-quality research-oriented universities provide a supportive environment for exploration and exploitation of new knowledge and development of entrepreneurial competences among students [83]. A university's research is seen as an important resource for aspiring entrepreneurs, which can result in new knowledge and technologies that can be eventually commercialized [64]. Singhry [84] reported that technological capabilities positively influence technopreneurial intentions. STEM students in universities characterized with research excellence may be more likely to have access to advanced knowledge, skills, the latest advancements and innovations, new technologies, and therefore may be more likely to perceive opportunities for technology entrepreneurship and to develop technopreneurial intentions. Such access to the latest scientific knowledge, technologies and inventions may also increase the perceptions of desirability and feasibility for technology entrepreneurship and eventually technopreneurial intentions versus other entrepreneurial intentions among STEM students. Therefore, we suggest that:

Hypothesis 4 (H4). University research excellence increases the likelihood of technopreneurial intentions among STEM students.

\section{Research Methodology}

This study utilized a database about technology entrepreneurship among Bulgarian science and engineering students. The database was collected using a cross-sectional survey among science and engineering students in Bulgarian universities to investigate the influence of entrepreneurship education on technopreneurial intentions and their antecedents. Science and engineering students were selected for the empirical analysis because they exhibit the potential to start technology ventures [47]. The survey was administrated to students in science or engineering majors in 15 Bulgarian universities in 2015 and 2016. The selected universities are located in Sofia and several other major Bulgarian cities. Rectors, deans and department heads in all Bulgarian universities providing bachelor and master programs in science and engineering study fields were contacted and invited to participate in the survey. Only 14 public universities and one private university expressed a consent to participate in the survey. A quota sampling technique was adopted for data collection based on the total number of science and engineering students enrolled in each university, which was obtained from the Ministry of Education and Science. The database has the same proportions of science and engineering students from the 
different universities as the entire population of science and engineering students enrolled in the selected 15 universities in the respective year in which the survey was conducted. The database includes 1061 students. Some of them are technology business owners or have started and manage a technology business for their employers. Others are in a process of starting a technology business for themselves or their employers. A third group of students exhibited technopreneurial intentions. The rest of the respondents did not report entrepreneurial intentions. The students in the database are enrolled in various study fields such as communication and computer equipment, informatics and computer sciences, biotechnologies, electrical engineering, electronics and automation, power engineering, transport, navigation and aviation, general engineering, biological sciences, chemical sciences, chemical technologies, architecture, construction and geodesy, earth sciences, minerals prospecting, extraction and processing, mechanics, energetics and food technologies. Students enrolled in the study fields of social sciences, humanities, medicine, national security and military science were excluded from the survey. The questionnaire used in the study includes questions which requested a broad array of information related to demographic characteristics of respondents, entrepreneurial intentions, attitudes toward entrepreneurship, entrepreneurial behaviour, and entrepreneurship education. In a short introduction about the aims of the survey in the questionnaire, technology entrepreneurship is defined as the creation of a new technology-based business, while technology-based business is described as a business whose products or services depend largely on the application of scientific or technological knowledge [85]. A pilot study was conducted among 15 students (8 males and 7 females) in order to pre-test the initial version of the questionnaire. Due to comments from some students, minor changes were introduced in some questions. With the approval and cooperation of rectors, deans, department heads and lecturers in 15 Bulgarian universities, a questionnaire was distributed during class sessions. Students were informed that participation in the survey was voluntary and that the questionnaires were only for research purposes. In the instructions to respondents with regard to the filling-in procedure, they were advised that the instrument should be completed anonymously and that it was important to answer all questions. In order to secure a high response rate, to monitor respondents while they were answering the questionnaire, and to be able to answer further questions from respondents, the author was present during the data collection in most occasions. If missing information was identified when the respondents were submitting the filled questionnaires, the respondents were politely asked to complete it. Questionnaires with missing answers were removed from the database and data collection from each university continued until the required quota fixed by the researcher was fulfilled. The sample for this study was extracted from the database and is composed of 337 STEM students who exhibit entrepreneurial intentions. They reported that they think they will start a business $[38,86]$. All respondents reporting entrepreneurial intentions were asked if they think they will start a technology business $[38,86]$. In the sample, 299 students reported that they think they will start a technology business $[38,86]$. They are neither business owners nor in a process of starting a business. More than $79 \%$ of the respondents in the sample are undergraduate students. Female students represented less than $41 \%$ of the sample. The great majority of the respondents are full-time students. Only $21.7 \%$ of the sample is composed of part-time students.

The dependent variable in this study is technopreneurial intentions (TECH_INT). It takes value 1 if the respondent thinks s/he will start a technology business $[38,86]$, and value 0 otherwise. As all respondents reported that they think they will start a business, the respondent who do not think they will start a technology business tend to exhibit entrepreneurial intentions to start a nontechnology business. The study employed several independent university-level and individual-level variables. The university-level variables include university research excellence, university support with concept development, and university support with business development, while the individual-level variable is participation in entrepreneurship education. The variable participation in entrepreneurship education (ENTR_EDU) takes value 1 if the respondent was/is enrolled in an entrepreneurship course within the university, and value 0 if not. The variable university research excellence (RES_EXC) is measured with the H-index of the university in the scientific field of study of the respondent in SCOPUS. 
Two perceptual measures of entrepreneurship development support provided by the university were adopted. It was suggested that, although universities can support entrepreneurship with objective measures, it is important to take into account the extent to which such objective measures can influence students by evaluating students' perceptions of entrepreneurship development support provided by the university [56]. The variable university support with concept development (CONCEPT_DEV) is measured with a four-item 7-point Likert scale developed by [56], which reveals students' perceptions of the university support for concept development beyond teaching. The scale exhibits high reliability (Cronbach's alpha $=0.910$ ). The variable university support with business development (BUS_DEV) is measured with a three-item 7-point Likert scale developed by [56], which reveals students' perceptions of the university support for starting and developing a new business (Cronbach's alpha $=0.669$ ). Both scales exhibit acceptable reliability which exceeds the minimum acceptable level of 0.6 [87].

The study controlled for individual differences related to the support from social networks, positive entrepreneurial role models, gender, willingness to take risks, perceived new technology venture feasibility and desirability, previous experience in a technology company. These variables have been identified as significant predictors of entrepreneurial intentions in the literature [21,36,44]. The variable perceived new technology venture feasibility (FEASIBILITY_TE) reveals new technology venture perceived feasibility and is measured with an index composed by 4 items measured on a 7-point Likert scale $[36,38,88]$. The Cronbach's alpha of the scale is 0.597 , which is close to the minimum acceptable level of 0.6 [87]. The variable perceived new technology venture desirability (DESIRABILITY_TE) indicates how desirable technology entrepreneurship is for respondents. It is measured with an index composed by 3 items measured on a 7 -point Likert scale $[36,38,88]$. The Cronbach's alpha of the scale is 0.719 . The variable willingness to take risks (RISK) indicates students' willingness to take risks and is measured with 4 items adopted from [89] (Cronbach's alpha $=0.736$ ). All scales exhibit acceptable reliability, which is roughly equal to or higher than the minimum acceptable level of 0.6 [87]. The variable positive entrepreneurial role models (ROLE_MODELS) takes value 1 if the respondent has at least one entrepreneur among parents, relatives, friends or acquaintances whose success gave her/him a positive impression of entrepreneurship [63], and value 0 otherwise. The variable support from social networks (SOC_NET_SUP) takes value 1 if the respondent can count on support from family, partner, friends and acquaintances if $s /$ he becomes an entrepreneur after his/her studies [64], and 0 otherwise. The variable gender (GENDER) takes value 1 if the respondent is male and value 0 if she is female. The variable previous experience in a technology company (TECH_EXP) takes value 1 if the respondent has previous professional experience in a technology company, and value 0 otherwise. Table 1 contains the description of the variables used in the study.

Table 1. Description of the variables used in the study.

\begin{tabular}{|c|c|}
\hline Variables & Description \\
\hline \multicolumn{2}{|l|}{ Dependent variable } \\
\hline TECH_EXP & $1=$ the respondent thinks s/he will start a technology business; $0=$ otherwise $[34,68]$ \\
\hline \multicolumn{2}{|l|}{$\begin{array}{l}\text { Independent } \\
\text { variables }\end{array}$} \\
\hline (ENTR_EDU) & $\begin{array}{l}1=\text { the respondent was/is enrolled in an entrepreneurship course within the } \\
\text { university; } 0=\text { otherwise }\end{array}$ \\
\hline RES_EXC & $\begin{array}{l}\text { the value of the H-index of the university in the scientific field of study of the } \\
\text { respondent in SCOPUS }\end{array}$ \\
\hline CONCEPT_DEV & a four-item 7-point Likert scale developed by [65] \\
\hline BUS_DEV & a three-item 7-point Likert scale developed by [65] \\
\hline \multicolumn{2}{|l|}{ Control variable } \\
\hline FEASIBILITY_TE & a four-item 7-point Likert scale $[36,38,88]$ \\
\hline
\end{tabular}


Table 1. Cont.

\begin{tabular}{|c|c|}
\hline Variables & Description \\
\hline DESIRABILITY_TE & a three-item 7 -point Likert scale $[36,38,88]$ \\
\hline RISK & a four-item 7-point Likert scale [89] \\
\hline ROLE_MODELS & $\begin{array}{l}1 \text { = the respondent has at least one entrepreneur among parents, relatives, friends or } \\
\text { acquaintances whose success gave her/him a positive impression of entrepreneurship; } \\
0=\text { otherwise [63] }\end{array}$ \\
\hline SOC_NET_SUP & $\begin{array}{l}1=\text { the respondent can count on support from family, partner, friends and } \\
\text { acquaintances if s/he becomes an entrepreneur after his/her studies; } 0 \text { otherwise [63] }\end{array}$ \\
\hline GENDER & $1=$ the respondent is male; $0=$ the respondent is female \\
\hline TECH_EXP & $\begin{array}{l}1 \text { = the respondent has previous professional experience in a technology company; } \\
\qquad 0=\text { otherwise }\end{array}$ \\
\hline
\end{tabular}

Taking into account the objectives of this study and the properties of the data, we applied a binary logistic regression for data analysis [90]. A binary logistic regression was employed to deal explicitly with the dependent variable TECH_INT, which is a binary variable [90]. The logistic regression is a more robust method since according to $[87,90,91]$ :

- the dependent variable needs not to be normally distributed;

- logistic regression does not assume a linear relationship between the dependent and the independent variables;

- the dependent variable needs not to be homoscedastic for each level of the independent variable(s);

- normally distributed error terms are not assumed;

- independent variables can be categorical;

- it does not require independent variables to be interval or unbounded.

The application of nonparametric techniques is adequate when the independent variables are predominantly categorical. The use of the maximum likelihood approach is recommended when sample selection bias is possible [92]. The data analysis was performed using version 25 of IBM SPSS Statistics.

\section{Empirical Evidence}

Correlations between independent and control variables employed in the study are relatively modest (not exceeding 0.3) (Table 2). Male students in our sample are more likely to have previous professional experience in a technology company. Female students are more likely to be enrolled in an entrepreneurship course and to report that they can count on support from family, partner, friends and acquaintances if they become entrepreneurs after their studies. Students in universities with better research exhibit lower willingness to take risks. Students with lower willingness to take risks tend to perceive lower new technology venture desirability. Students with more positive perceptions of concept and business development support report higher perceived new technology venture feasibility. Students with higher perceived new technology venture desirability also exhibit higher perceived new technology venture feasibility.

A binary logistic regression exploring the effects of university-level factors and individual-level factors related to the university on the likelihood of technopreneurial intentions is presented in Table 3 . The model is significant at $99 \%$ confidence level according to Chi-square statistics. Therefore, the null hypothesis that all coefficients (except the constant) are zero can be rejected. The variance of inflation factor (VIF) is used as a check on multicollinearity. The VIFs for the variables in the regression indicate that there are no serious multicollinearity problems, as they are all within the acceptable limits (less than 4). The overall predictive ability of the model to correctly classify students by their technopreneurial intentions is $89.1 \%$. The variable RES_EXC significantly and positively 
influences the odds of technopreneurial intentions. Students in research-oriented universities are more likely to exhibit technopreneurial intentions than other entrepreneurial intentions $(p<0.01)$. Hypothesis 4 cannot be rejected. The variable BUS_DEV positively affects the odds of technopreneurial intentions. Students perceiving greater university support for business development are more likely to exhibit technopreneurial intentions $(p<0.10)$. These results provide weak support for Hypothesis 3 . The coefficients of the variables ENTR_EDU and CONCEPT_DEV are not significant. Participation in entrepreneurship education and perceptions of university support with concept development are not related to the likelihood of technopreneurial intentions. Hypotheses 1 and 2 can be rejected.

Table 2. Correlation matrix.

\begin{tabular}{|c|c|c|c|c|c|c|c|c|c|c|c|}
\hline & Variables & 1 & 2 & 3 & 4 & 5 & 6 & 7 & 8 & 9 & 10 \\
\hline 1 & GENDER & 1 & & & & & & & & & \\
\hline 2 & RISK & 0.02 & 1 & & & & & & & & \\
\hline 3 & TECH_EXP & $0.16^{* *}$ & 0.00 & 1 & & & & & & & \\
\hline 4 & ROLE_MODELS & 0.05 & -0.05 & -0.06 & 1 & & & & & & \\
\hline 5 & SOC_NET_SUP & $-0.14 *$ & 0.02 & 0.04 & -0.07 & 1 & & & & & \\
\hline 6 & ENTR_EDU & $-0.22 * *$ & -0.1 & 0.05 & -0.02 & 0.06 & 1 & & & & \\
\hline 7 & CONCEPT_DEV & $-0.12 *$ & 0.01 & 0.05 & -0.04 & -0.00 & $0.15^{* *}$ & 1 & & & \\
\hline 8 & BUS_DEV & -0.08 & 0.1 & 0.00 & -0.05 & -0.04 & 0.09 & $0.62 * *$ & 1 & & \\
\hline 9 & RES_EXC & -0.07 & $-0.14^{* *}$ & -0.02 & $0.13^{*}$ & 0.03 & 0.07 & -0.05 & -0.06 & 1 & \\
\hline 10 & DESIRABILITY_TE & -0.01 & $-0.14^{* *}$ & -0.05 & 0.06 & 0.08 & 0.02 & 0.1 & 0.05 & 0.01 & 1 \\
\hline 11 & FEASIBILITY_TE & -0.06 & -0.01 & -0.08 & -0.007 & 0.09 & 0.1 & $0.22 * *$ & $0.20^{* *}$ & $-0.12 *$ & $0.30^{* *}$ \\
\hline
\end{tabular}

Table 3. Results from a binary logistic regression $\left(\right.$ dependent variable $=$ TECH_INT) ${ }^{a}$.

\begin{tabular}{|c|c|c|c|c|c|}
\hline Variable & B & S.E. & Wald & Sig. & $\operatorname{Exp}(B)$ \\
\hline RES_EXC & 0.134 & 0.045 & 8.693 & 0.003 & 1.143 \\
\hline ENTR_EDU & 0.475 & 0.435 & 1.190 & 0.275 & 1.607 \\
\hline CONCEPT_DEV & -0.020 & 0.039 & 0.267 & 0.605 & 0.980 \\
\hline BUS_DEV & 0.104 & 0.058 & 3.160 & 0.075 & 1.109 \\
\hline FEASIBILITY_TE & 0.012 & 0.043 & 0.081 & 0.776 & 1.012 \\
\hline DESIRABILITY_TE & 0.206 & 0.057 & 13.206 & 0.000 & 1.229 \\
\hline GENDER & 0.513 & 0.417 & 1.514 & 0.219 & 1.670 \\
\hline RISK & -0.003 & 0.038 & 0.008 & 0.929 & 0.997 \\
\hline ROLE_MODELS & 0.394 & 0.410 & 0.922 & 0.337 & 1.483 \\
\hline SOC_NET_SUP & -0.032 & 0.479 & 0.004 & 0.947 & 0.969 \\
\hline TECH_EXP & -0.369 & 0.342 & 1.166 & 0.280 & 0.691 \\
\hline-2 Log likelihood & 196.848 & & & & \\
\hline Nagelkerke R-Square & 0.217 & & & & \\
\hline Model Chi-square & 38.628 & & & & \\
\hline Overall correct predictions & $89.1 \%$ & & & & \\
\hline
\end{tabular}

The control variables DESITABILITY_TE exert a significant influence on the likelihood of technopreneurial intentions $(p<0.001)$. Students with greater new technology venture desirability are more likely to have technopreneurial intentions. The variables GENDER, SOC_NET_SUP, 
ROLE_MODELS, RISK, FEASIBILITY_TE and EXP_TE have no significant effects on the dependent variable.

\section{Discussion and Conclusions}

In a knowledge-based economy, entrepreneurship is a driving force for economic development [93]. In particular, technology entrepreneurship, which is at the crossroad of entrepreneurship and technology-based innovation [8], may play a vital role in enhancing sustainable development. Universities need to operate more entrepreneurially and to create favourable conditions for entrepreneurship and innovation at all its levels [94]. To date, a large number of studies have focused on students' entrepreneurial intentions to gain understanding of their future entrepreneurial behaviour. This study examined factors related to the university at both the individual and organizational levels, which are associated with the incidence of technopreneurial intentions using a sample of 337 Bulgarian STEM students with entrepreneurial intentions. The proposed conceptual model posits that participation in entrepreneurship education, university support for entrepreneurship and university research excellence determine the formation of technopreneurial intentions among STEM students. The study controlled for other individual-level differences related to the support from social networks, positive entrepreneurial role models, gender, willingness to take risks, perceived new technology venture feasibility and desirability, previous experience in a technology company.

Our findings reveal that the university environment influences the odds of technopreneurial intentions. University research excellence has a strong positive impact on the odds of technopreneurial intentions, while university support with business development weakly and positively affects the odds of technopreneurial intentions. University support with concept development has no significant effect on the likelihood of technopreneurial intentions. These findings are in line with previous empirical evidence about the role of university support in entrepreneurial intentions among students [56,65-67,95] and reinforce the direct contextual link with entrepreneurial intentions [96]. It seems that students with entrepreneurial intentions in universities providing greater business development support may gain confidence for technopreneurial venturing [56]. The weak statistical significance of the effect of the university support with business development and the lack of statistical significance of the effect of the university support with concept development on the odds of students' techopreneurial intentions may be explained by the fact that these variables do not account particularly for the university support with concept development for technology entrepreneurship and university support for technology business development. University support specifically targeted at encouraging technology entrepreneurship may influence more strongly the formation of technopreneurial intentions among STEM students.

As expected, students in universities with better research in their scientific field of study are more likely to exhibit technopreneurial intention, which is in contradiction with previous findings that university research orientation negatively influences students' self-employment intentions [64] and is in line with previous research demonstrating that technology entrepreneurs often have a "research" background [97]. Although Bulgarian universities encounter significant internal and external barriers to their transformation into entrepreneurial universities [98], our study demonstrates that Bulgarian universities offering educational programs in STEM fields have the capacity to foster technology entrepreneurship among students and thus to contribute to entrepreneurial activity and innovation in the economy. Our empirical results support previous claims that universities may play an important role in the regional entrepreneurship and innovation ecosystem [99].

Surprisingly, participation in entrepreneurship education is not related to a higher likelihood of technopreneurial intentions. The lack of significant effect of entrepreneurship education on the dependent variable may be due to the general nature of entrepreneurship education in the studied universities. Such general entrepreneurship educations may not be suited to the specific needs of STEM students and may not be able to encourage the formation of technopreneurial intentions. These results contradict previous evidence about the role of entrepreneurship education for entrepreneurial intentions [61,99-101] and highlight the need to tailor entrepreneurship education 
to suit a particular target group [102]. They raise the question about what contents and teaching methods are used in entrepreneurship courses for STEM students at the studied universities and to what extent they are conductive for the formation of technopreneurial intentions. Past research results conceive of entrepreneurial learning as an experiential process [103]. Hence, entrepreneurship education should go beyond promoting awareness and providing knowledge [104] and should focus on real-world experience, action, and reflection to increase technopreneurial intentions and eventually to enhance entrepreneurial performance [105]. Entrepreneurship courses and programs specifically targeted at STEM students should help them to overcome specific constraints and obstacles such as lack of entrepreneurial skills and skills for start-up development, aversion to financial and bureaucracy issues, lack of knowledge in the management field, and lack of market focus [69].

The control variables employed in the study do not have a statistically significant effect on the odds of technopreneurial intentions, except for the perceived desirability for technology entrepreneurship. Previous research reveals the importance of entrepreneurial role models for the formation of entrepreneurial intentions [106]. The key functions of entrepreneurial role models include inspiration and motivation to get started, increased entrepreneurial self-efficacy, learning by example, and learning by support [106]. The present study demonstrates that entrepreneurial role models are not more conductive for the formation of technopreneurial intentions. Students with higher perceived desirability for technology entrepreneurship exhibit higher odds of technopreneurial intentions. Perceived feasibility has no effect on the odds of technopreneurial intentions versus other intentions. Although willingness to take risk is an important trait related to entrepreneurship $[107,108]$, the evidence suggests that willingness to take risk does not affect the odds of technopreneurial intentions in our sample. An important finding is that gender is not associated with the odds of technopreneurial intentions. It seems that factors that constrain women's entrepreneurial intentions compared to men do not affect in the same way the formation of technopreneurial intentions among women. Contrary to prior claims that stronger social network support may provide needed resources for entrepreneurship, and thus is associated with entrepreneurial choice [64], this study did not find a link between social network support and the odds of technopreneurial intentions. Although previous research suggests that specific knowledge acquired through previous work experience facilitates the discovery of new opportunities [58], this study demonstrates that previous experience in a technology company is not related to the likelihood of technopreneurial intentions. These results imply that determinants of entrepreneurial intentions identified in the literature such as entrepreneurial role models, perceived support from social networks, willingness to take risks and gender may not be relevant specifically for technopreneurial intentions.

Our cross-level study on university-level and individual-level factors related to the university associated with the incidence of technopreneurial intentions among Bulgarian STEM students extends the literature in several ways. Our study contributes to the literature on the role of university for student entrepreneurship by providing evidence about the influence of various factors related to the university at two levels (university level and individual level), which helps to understand the context in which some pre-venture processes occur [64]. Given the increasing importance of student entrepreneurship, this research enhances our understanding about how universities can better stimulate and support the entrepreneurial efforts of students. The findings of this research highlight the importance of the university research excellence and university support for entrepreneurship development. The presented empirical evidence reinforces the view of university as a driver of entrepreneurship and innovation [1] and contributes to the debate about the role of institutional underpinnings in national innovation systems [109]. This study extends the literature on technology entrepreneurship, which lacks significant research attention to pre-venture processes, by identifying determinants of technopreneurial intentions. It contributes to the literature on entrepreneurial intentions by underscoring the need not to regard this construct as homogeneous and to direct research attention to different types of entrepreneurial intentions. 
The study has several limitations that should be discussed explicitly before outlining recommendations for future research. A major limitation of this research is the cross-sectional study design, which does not allow to make inferences about causal relationships. The use of cross-sectional data does not allow to control for unobservable fixed effects that may affect both the dependent and the independent variables such as student's capabilities [84]. The study does not address possible endogeneity in the proposed regression model. The size of the sample is not large, and the variability of the dependent variable is rather low. The data were collected through a self-reported survey, and thus may be subjected to cognitive biases and errors. The findings may be influenced by specific features of the Bulgarian cultural and institutional environment, and therefore may not be applicable to other countries and contexts.

The reported empirical findings and the outlined limitations of the study open several new directions for future research. First, the presented conceptual model should be modified to include the constructs university support with concept development for technology entrepreneurship and university support with technology business development. Thus, future research should test the modified conceptual model in large, representative samples drawn from Bulgaria and other countries, in order to determine to what extent our findings are applicable to both the Bulgarian context and other contexts. Second, future research should investigate the role of entrepreneurship education for fostering entrepreneurial intentions and behaviour among STEM students and should provide greater understanding of the impact of various educational variables related to entrepreneurship education such as teaching methods, learning outcomes, educator teaching beliefs, etc., on students' technopreneurial intentions and behaviour. Third, future research should devote greater attention to different types of entrepreneurial intentions and should clarify which determinants of entrepreneurial intentions identified in the literature are relevant particularly for technopreneurial intentions. Forth, future research should provide greater understanding about the role of universities for knowledge and technology transfer, focusing, in particular, on student involvement in the early stages of the entrepreneurial process. Future studies need to investigate the impact of the university ecosystem for entrepreneurship and innovation and to identify effective entrepreneurship support services and activities that stimulate students' technopreneurial intentions. The identification of cases of success can help to formulate best practices that can guide universities into developing their internal ecosystems for entrepreneurship and innovation. Future research with longitudinal design is necessary to provide insights about university-related factors at the individual and organizational levels that contribute to technopreneurial intentions.

The findings from this study have important policy implications. Policy makers involved in national and regional development issues should be aware of the key role universities may play in regional entrepreneurship and innovation systems. University managers and policy makers concerned with enhancing the 'third mission' of universities should be aware of the important role of university research excellence and specific university support for stimulating technopreneurial intentions and behaviour of students. They should adopt the view of universities as entrepreneurship and innovation ecosystems and make specific efforts to promote diverse entrepreneurship and innovation support structures and activities within universities for stimulating and supporting technology entrepreneurship, involve a variety of entrepreneurs such as students, faculty members and alumni, and attract internal and external support actors and investors. Policies aimed at increasing and improving research output in STEM fields of Bulgarian universities may contribute to fostering entrepreneurship and innovation at the regional level in the long term [77]. Educators teaching entrepreneurship to STEM students should adopt more tailored approaches to entrepreneurship education that suit the specific characteristics, needs and obstacles experienced by this specific group of students. There is a need for introducing contents and teaching methods which allow for gaining real-world experience and promote experimentation, risk-taking, action and reflection in entrepreneurship courses and programs for STEM students. 
Author Contributions: Conceptualization, D.Y., J.A.F. and M.P.C.; Methodology, D.Y., J.A.F. and M.P.C.; Software, D.Y. and J.A.F.; Validation, D.Y., J.A.F. and M.P.C.; Formal analysis, D.Y., J.A.F. and M.P.C.; Investigation, D.Y., J.A.F. and M.P.C.; Resources, D.Y., J.A.F. and M.P.C.; Data curation, D.Y. and J.A.F.; Writing-review and editing, D.Y. and J.A.F.; Visualization, D.Y. and M.P.C.; Supervision, D.Y.; Project administration, D.Y. and M.P.C.; Funding acquisition, D.Y. and M.P.C. All authors have read and agreed to the published version of the manuscript.

Funding: The first author acknowledges financial support from the Scientific Research Fund of Sofia University "St. Kliment Ohridski" (contract N 80-10-232/13.05.2020). This research was also funded by FCT (Fundação para a Ciência e Tecnologia), grant number UIDB/04521/2020.

Acknowledgments: The authors thank the Sofia University "St. Kliment Ohridski”, the Iscte-Instituto Universitário de Lisboa, ISTAR-IUL and ISEG/Universidade de Lisboa for their support, which are acknowledged. They finally thank three anonymous reviewers for their valuable comments.

Conflicts of Interest: The authors declare no conflict of interest.

\section{References}

1. Guerrero, M.; Urbano, D.; Fayolle, A.; Klofsten, M.; Mian, S. Entrepreneurial universities: Emerging models in the new social and economic landscape. Small Bus. Econ. 2016, 47, 551-563. [CrossRef]

2. Markkula, M.; Kune, H. Making smart regions smarter: Smart specialization and the role of universities in regional innovation ecosystems. Technol. Innov. Manag. Rev. 2015, 5, 7-15. [CrossRef]

3. Åstebro, T.; Bazzazian, N.; Braguinsky, S. Startups by recent university graduates and their faculty: Implications for university entrepreneurship policy. Res. Policy 2012, 41, 663-677. [CrossRef]

4. Martin, B.C.; McNally, J.J.; Kay, M.J. Examining the formation of human capital in entrepreneurship: A meta-analysis of entrepreneurship education outcomes. J. Bus. Ventur. 2013, 28, 211-224. [CrossRef]

5. Dickson, P.H.; Solomon, G.T.; Weaver, K.M. Entrepreneurial selection and success: Does education matter? J. Small Bus. Enterp. Dev. 2008, 15, 239-258. [CrossRef]

6. Pittaway, L.; Cope, J. Entrepreneurship Education: A Systematic Review of the Evidence. Int. Small Bus. J. 2007, 25, 479-510. [CrossRef]

7. Wright, M.; Siegel, D.S.; Mustar, P. An emerging ecosystem for student start-ups. J. Technol. Transf. 2017, 42, 909-922. [CrossRef]

8. Beckman, C.M.; Eisenhardt, K.; Kotha, S.; Meyer, A.; Rajagopalan, N. The role of the entrepreneur in technology entrepreneurship. Strateg. Entrep. J. 2012, 6, 203-206. [CrossRef]

9. UN General Assembly. Entrepreneurship for Sustainable Development; Resolution Adopted by the General Assembly on 21 December 2016; United Nations: New York, NY, USA, 2016.

10. Hall, J.K.; Daneke, G.A.; Lenox, M.J. Sustainable development and entrepreneurship: Past contributions and future directions. J. Bus. Ventur. 2010, 25, 439-448. [CrossRef]

11. Filser, M.; Kraus, S.; Roig-Tierno, N.; Kailer, N.; Fischer, U. Entrepreneurship as catalyst for sustainable development: Opening the black box. Sustainability 2019, 11, 4503. [CrossRef]

12. UN General Assembly. Transforming our World: The 2030 Agenda for Sustainable Development; Resolution Adopted by the General Assembly on 25 September 2015; United Nations: New York, NY, USA, 2015.

13. Kardos, M. The Relationship between Entrepreneurship, Innovation and Sustainable Development. Research on European Union Countries. Procedia Econ. Financ. 2012, 3, 1030-1035. [CrossRef]

14. Ratinho, T.; Harms, R.; Walsh, S. Structuring the Technology Entrepreneurship publication landscape: Making sense out of chaos. Technol. Forecast. Soc. Chang. 2015, 100, 168-175. [CrossRef]

15. Shane, S.; Venkataraman, S. Guest editors' introduction to the special issue on technology entrepreneurship. Res. Policy 2003, 32, 181-184. [CrossRef]

16. Mosey, S.; Guerrero, M.; Greenman, A. Technology entrepreneurship research opportunities: Insights from across Europe. J. Technol. Transf. 2017, 42,1-9. [CrossRef]

17. Mosey, S. Teaching and research opportunities in technology entrepreneurship. Technovation 2016, 57, 43-44. [CrossRef]

18. Bailetti, T. Technology entrepreneurship: Overview, definition, and distinctive aspects. Technol. Innov. Manag. Rev. 2012, 2, 5-12. [CrossRef]

19. Lee, S.H.; Wong, P.K. An exploratory study of technopreneurial intentions: A career anchor perspective. J. Bus. Ventur. 2004, 19, 7-28. [CrossRef] 
20. Carey, T.A.; Flanagan, D.J.; Palmer, T.B. An examination of university student entrepreneurial intentions by type of venture. J. Dev. Entrep. 2010, 15, 503-517. [CrossRef]

21. Liñán, F.; Fayolle, A. A systematic literature review on entrepreneurial intentions: Citation, thematic analyses, and research agenda. Int. Entrep. Manag. J. 2015, 11, 907-933. [CrossRef]

22. Fayolle, A.; Liñán, F. The future of research on entrepreneurial intentions. J. Bus. Res. 2014, 67, 663-666. [CrossRef]

23. Burgelman, R.A.; Christensen, C.M.; Wheelwright, S.C. Strategic Management of Technology and Innovation; International Edition; McGraw Hill: New York, NY, USA, 2004.

24. Petti, C.; Zhang, S. Factors influencing technological entrepreneurship capabilities: Towards an integrated research framework for Chinese enterprises. J. Technol. Manag. China 2011, 6, 7-25. [CrossRef]

25. Petti, C. Cases in Technological Entrepreneurship: Converting Ideas into Value; Edward Elgar: Northampton, MA, USA, 2009.

26. Garud, R.; Karnøe, P. Bricolage versus breakthrough: Distributed and embedded agency in technology entrepreneurship. Res. Policy 2003, 32, 277-300. [CrossRef]

27. Hsu, D.H. Technology-Based Entrepreneurship. Handbook of Technology and Innovation Management; Blackwell Publishers, Ltd.: Oxford, UK, 2008; pp. 367-387.

28. Gans, J.S.; Stern, S. The Product Market and the Market for Ideas: Commercialization Strategies for Technology Entrepreneurs. Res. Policy 2003, 32, 333-350. [CrossRef]

29. Antoncic, B.; Prodan, I. Alliances, corporate technological entrepreneurship and firm performance: Testing a model on manufacturing firms. Technovation 2008, 28, 257-265. [CrossRef]

30. Colovic, A.; Lamotte, O. Technological Environment and Technology Entrepreneurship: A Cross-Country Analysis. Creat. Innov. Manag. 2015, 24, 617-628. [CrossRef]

31. Spiegel, M.; Marxt, C. Defining Technology Entrepreneurship. In Proceedings of the 2011 IEEE International Conference on Industrial Engineering and Engineering Management, Singapore, 6-9 December 2011; IEEE: Piscataway, NJ, USA, 2011; pp. 1623-1627.

32. Pathak, S.; Xavier-Oliveira, E.; Laplume, A.O. Influence of intellectual property, foreign investment, and technological adoption on technology entrepreneurship. J. Bus. Res. 2013, 66, 2090-2101. [CrossRef]

33. Phan, P.H.; Foo, M. Technological entrepreneurship in emerging regions. J. Bus. Ventur. 2004, 19, 1-5. [CrossRef]

34. McPhee, C.; Bailetti, T. Editorial: Technology Entrepreneurship. Technol. Innov. Manag. Rev. 2012, 2, 3-4.

35. Bird, B. Implementing entrepreneurial ideas: The case for intention. Acad. Manag. Rev. 1988, 13, 442-453. [CrossRef]

36. Krueger, N.; Reilly, M.; Carsrud, A. Competing models of entrepreneurial intentions. J. Bus. Ventur. 2000, 15, 411-432. [CrossRef]

37. Krueger, N.F.; Carsrud, A.L. Entrepreneurial intentions: Applying the theory of planned behaviour. Entrep. Reg. Dev. 1993, 5, 315-330. [CrossRef]

38. Krueger, N.F. The impact of prior entrepreneurship exposure on perception of new venture feasibility and desirability. Entrep. Theory Pract. 1993, 18, 5-21. [CrossRef]

39. Kolvereid, L. Organizational employment versus self-employment: Reasons for career choice intentions. Entrep. Theory Pract. 1996, 20, 23-31. [CrossRef]

40. MacMillan, I.; Katz, J. Idiosyncratic milieus of entrepreneurship research: The need for comprehensive theories. J. Bus. Ventur. 1992, 7, 1-8. [CrossRef]

41. Shapero, A.; Sokol, L. The social dimensions of entrepreneurship. In Encylclopedia of Entrepreneurship; Kent, C.A., Sexton, D.L., Vesper, K.H., Eds.; Prentice-Hall: Englewood Cliffs, NJ, USA, 1982; pp. 72-90.

42. Ajzen, I. Theory of planned behaviour. Organ. Behav. Hum. Decis. Process. 1991, 50, 179-211. [CrossRef]

43. Veciana, J.M.; Aponte, M.; Urbano, D. University students' attitudes towards entrepreneurship: A two countries comparison. Int. Entrep. Manag. J. 2005, 1, 165-182. [CrossRef]

44. Lüthje, C.; Franke, N. The 'making' of an entrepreneur: Testing a model of entrepreneurial intent among engineering students at MIT. RED Manag. 2003, 33, 135-147.

45. Martínez-González, J.A.; Kobylinska, U.; García-Rodríguez, F.J.; Nazarko, L. Antecedents of Entrepreneurial Intention among Young People: Model and Regional Evidence. Sustainability 2019, 11, 6993. [CrossRef]

46. Tkachev, A.; Kolvereid, L. Self-employment intentions among Russian students. Entrep. Reg. Dev. 1999, 11, 269-280. [CrossRef] 
47. Souitaris, V.; Zerbinati, S.; Al-Laham, A. Do entrepreneurship programmes raise entrepreneurial intention of science and engineering students? The effect of learning, inspiration and resources. J. Bus. Ventur. 2007, 22, 566-591. [CrossRef]

48. Hmieleski, K.M.; Corbett, C. Proclivity for improvisation as a predictor of entrepreneurial intentions. J. Small Bus. Manag. 2006, 44, 45-63. [CrossRef]

49. De Pillis, E.; Reardon, K. The influence of personality traits and persuasive messages on entrepreneurial intention: A cross-cultural comparison. Career Dev. Int. 2007, 12, 382-396. [CrossRef]

50. Etzkowitz, H. Research groups as 'quasi firms': The invention of the entrepreneurial university. Res. Policy 2003, 32, 109-121. [CrossRef]

51. Graham, R. Creating University-Based Entrepreneurial Ecosystems: Evidence from Emerging World Leaders. MIT Skoltech Initiative. 2014. Available online: http://www.rhgraham.org/RHG/Recent_publications_ files/MIT\%3ASkoltech\%20entrepreneurial\%20ecosystems\%20report\%202014\%20_1.pdf (accessed on 15 June 2020).

52. Etzkowitz, H.; Webster, A.; Gebhardt, C.; Terra, B.R.C. The future of the university and the university of the future: Evolution of ivory tower to entrepreneurial paradigm. Res. Policy 2000, 29, 313-330. [CrossRef]

53. Rothaermel, F.T.; Agung, S.D.; Jiang, L. University Entrepreneurship: Taxonomy of the literature. Ind. Corp. Chang. 2007, 16, 691-791. [CrossRef]

54. Breznitz, S.M.; Zhang, Q. Fostering the growth of student start-ups from university accelerators: An entrepreneurial ecosystem perspective. Ind. Corp. Chang. 2019, 28, 855-873. [CrossRef]

55. Guenther, J.; Wagner, K. Getting out of the ivory tower-new perspectives on the entrepreneurial university. Eur. J. Int. Manag. 2008, 2, 400-417. [CrossRef]

56. Kraaijenbrink, J.; Bos, G.; Groen, A. What do students think of the entrepreneurial support given by their universities? Int. J. Entrep. Small Bus. 2010, 9, 110-125. [CrossRef]

57. Johannisson, B. University training for entrepreneurship: A Swedish approach. Entrep. Reg. Dev. 1991, 3, 67-82. [CrossRef]

58. Falkäng, J.; Alberti, F. The assessment of entrepreneurship education. Ind. High. Educ. 2000, 14, 101-108. [CrossRef]

59. Shane, S. Prior knowledge and the discovery of entrepreneurial opportunities. Organ. Sci. 2000, 11, 448-469. [CrossRef]

60. Hahn, D.; Minola, T.; Bosio, G.; Cassia, L. The impact of entrepreneurship education on university students' entrepreneurial skills: A family embeddedness perspective. Small Bus. Econ. 2020, 55, 257-282. [CrossRef]

61. Rideout, E.C.; Gray, D.O. Does entrepreneurship education really work? A review and methodological critique of the empirical literature on the effects of university-based entrepreneurship education. J. Small Bus. Manag. 2013, 51, 329-351. [CrossRef]

62. Bae, T.J.; Qian, S.; Miao, C.; Fiet, J.O. The relationship between entrepreneurship education and entrepreneurial intentions: A meta-analytic review. Entrep. Theory Pract. 2014, 38, 217-254. [CrossRef]

63. Hoque, A.S.M.M.; Awang, Z.; Siddiqui, B.A. Technopreneurial intention among university students of business courses in Malaysia: A structural equation modeling. Int. J. Entrep. Small Medium Enterp. 2017, 4, $1-16$.

64. Walter, S.G.; Parboteeah, K.P.; Walter, A. University departments and self-employment intentions of business students: A cross-level analysis. Entrep. Theory Pract. 2013, 37, 175-200. [CrossRef]

65. Trivedi, R. Does university play significant role in shaping entrepreneurial intention? A cross-country comparative analysis. J. Small Bus. Enterp. Dev. 2016, 23, 790-811. [CrossRef]

66. Mustafa, M.J.; Hernandez, E.; Mahon, C.; Chee, L.K. Entrepreneurial intentions of university students in an emerging economy: The influence of university support and proactive personality on students' entrepreneurial intention. J. Entrep. Emerg. Econ. 2016, 8, 162-179. [CrossRef]

67. Saeed, S.; Yousafzai, S.Y.; Yani De Soriano, M.; Muffatto, M. The role of perceived university support in the formation of students' entrepreneurial intention. J. Small Bus. Manag. 2015, 53, 1127-1145. [CrossRef]

68. Minola, T.; Donina, D.; Meoli, M. Students climbing the entrepreneurial ladder: Does university internationalization pay off? Small Bus. Econ. 2016, 47, 565-587. [CrossRef]

69. Paço, A.; Ferreira, J.; Raposo, M. How to foster young scientists' entrepreneurial spirit? Int. J. Entrep. 2017, 21, 47-60. 
70. Meoli, M.; Vismara, S. University support and the creation of technology and non-technology academic spin-offs. Small Bus. Econ. 2016, 47, 345-362. [CrossRef]

71. D'Este, P.; Mahdi, S.; Neely, A.; Rentocchini, F. Inventors and entrepreneurs in academia: What types of skills and experience matter? Technovation 2012, 32, 293-303. [CrossRef]

72. Di Gregorio, D.; Shane, S. Why do some universities generate more start-ups than others? Res. Policy 2003, 32, 209-227. [CrossRef]

73. Van Looy, B.; Landoni, P.; Callaert, J.; Van Pottelsberghe, B.; Sapsalis, E.; Debackere, K. Entrepreneurial effectiveness of European universities: An empirical assessment of antecedents and trade-offs. Res. Policy 2011, 40, 553-564. [CrossRef]

74. Rasmussen, E.; Mosey, S.; Wright, M. The influence of university departments on the evolution of entrepreneurial competencies in spin-off ventures. Res. Policy 2014, 43, 92-106. [CrossRef]

75. Acs, Z.J.; Audretsch, D.B.; Lehmann, E.E. The knowledge spillover theory of entrepreneurship. Small Bus. Econ. 2013, 41, 757-774. [CrossRef]

76. Audretsch, D.B.; Lehmann, E.E. Does the knowledge spillover theory of entrepreneurship hold for regions? Res. Policy 2005, 34, 1191-1202. [CrossRef]

77. Fritsch, M.; Aamoucke, R. Regional public research, higher education, and innovative start-ups: An empirical investigation. Small Bus. Econ. 2013, 41, 865-885. [CrossRef]

78. Ghio, N.; Guerini, M.; Lehmann, E.E.; Rossi-Lamastra, C. The emergence of the knowledge spillover theory of entrepreneurship. Small Bus. Econ. 2015, 44, 1-18. [CrossRef]

79. Ghio, N.; Guerini, M.; Rossi-Lamastra, C. The creation of high-tech ventures in entrepreneurial ecosystems: Exploring the interactions among university knowledge, cooperative banks, and individual attitudes. Small Bus. Econ. 2019, 52, 523-543. [CrossRef]

80. Amoroso, S.; Audretsch, D.B.; Link, A.N. Sources of knowledge used by entrepreneurial firms in the European high-tech sector. Eurasian Bus. Rev. 2018, 8, 55-70. [CrossRef]

81. Barbosa, N.; Faria, A.P. The effect of entrepreneurial origin on firms' performance: The case of Portuguese academic spinoffs. Ind. Corp. Chang. 2020, 29, 25-42. [CrossRef]

82. Bonaccorsi, A.; Colombo, M.G.; Guerini, M.; Rossi-Lamastra, C. The impact of local and external university knowledge on the creation of knowledge-intensive firms: Evidence from the Italian case. Small Bus. Econ. 2014, 43, 261-287. [CrossRef]

83. Beyhan, B.; Findik, D. Student and graduate entrepreneurship: Ambidextrous universities create more nascent entrepreneurs. J. Technol. Transf. 2018, 43, 1346-1374. [CrossRef]

84. Singhry, H.B. The effect of technology entrepreneurial capabilities on technopreneurial intention of nascent graduates. Eur. J. Bus. Manag. 2015, 7, 8-20.

85. Allen, J.C. Starting a Technology Business; Pitman: London, UK, 1992.

86. Peterman, N.; Kennedy, J. Enterprise education: Influencing students' perceptions of entrepreneurship. Entrep. Theory Pract. 2003, 8628, 129-144. [CrossRef]

87. Hair, F.J.; Anderson, E.R.; Tathan, L.R.; Black, C. Multivariate Data Analysis, 5th ed; Prentice Hall: Upper Saddle River, NJ, USA, 1998.

88. Drennan, J.; Kennedy, J.; Renfrow, P. Impact of childhood experiences on the development of entrepreneurial intentions. Int. J. Entrep. Innov. 2005, 6, 231-238. [CrossRef]

89. Gomez-Mejia, L.R.; Balkin, D.B. Effectiveness of individual and aggregate compensation strategies. Ind. Relat. 1989, 28, 431-445. [CrossRef]

90. Greene, W.H. Econometric Analysis; Prentice Hall: Upper Saddle River, NJ, USA, 1997.

91. Maddala, G. Limited Dependent and Qualitative Variables in Econometrics; Cambridge University Press: New York, NY, USA, 1983.

92. Nawata, K. Estimation of sample selection bias models by the maximum likelihood estimator and Heckman's two-step estimator. Econ. Lett. 1994, 45, 33-40. [CrossRef]

93. Audretsch, D.; Thurik, R. What's new about the new economy? Sources of growth in the managed and entrepreneurial economies. Ind. Corp. Chang. 2001, 10, 267-315. [CrossRef]

94. Kirby, D.A. Entrepreneurship education: Can business schools meet the challenge? International Entrepreneurship Education. In International Entrepreneurship Education: Issues and Newness; Fayolle, A., Klandt, H., Eds.; Edward Elgar Publishing: Northampton, MA, USA, 2006; pp. 35-54. 
95. Arrighetti, A.; Caricati, L.; Landini, F.; Monacelli, N. Entrepreneurial intention in the time of crisis: A field study. Int. J. Entrep. Behav. Res. 2016, 22, 835-859. [CrossRef]

96. Nabi, G.; Liñán, F. Considering business start-up in recession time. Int. J. Entrep. Behav. Res. 2013, 19, 633-655. [CrossRef]

97. Jones-Evans, D. A typology of technology-based entrepreneurs: A model based on previous occupational background. Int. J. Entrep. Behav. Res. 1995, 1, 26-47. [CrossRef]

98. Yordanova, D.; Filipe, J.A. Towards entrepreneurial universities: Barriers, facilitators, and best practices in Bulgarian and Portuguese universities. Int. J. Econ. Bus. Adm. 2019, 7, 213-227. [CrossRef]

99. Portuguez Castro, M.; Ross Scheede, C.; Gómez Zermeño, M.G. The Impact of Higher Education on Entrepreneurship and the Innovation Ecosystem: A Case Study in Mexico. Sustainability 2019, 11, 5597. [CrossRef]

100. Asimakopoulos, G.; Hernández, V.; Peña Miguel, J. Entrepreneurial intention of engineering students: The role of social norms and entrepreneurial self-efficacy. Sustainability 2019, 11, 4314. [CrossRef]

101. Vodă, A.I.; Florea, N. Impact of personality traits and entrepreneurship education on entrepreneurial intentions of business and engineering students. Sustainability 2019, 11, 1192. [CrossRef]

102. Maresch, D.; Harms, R.; Kailer, N.; Wimmer-Wurm, B. The impact of entrepreneurship education on the entrepreneurial intention of students in science and engineering versus business studies university programs. Technol. Forecast. Soc. Chang. 2016, 104, 172-179. [CrossRef]

103. Secundo, G.; Del Vecchio, P.; Schiuma, G.; Passiante, G. Activating entrepreneurial learning processes for transforming university students' idea into entrepreneurial practices. Int. J. Entrep. Behav. Res. 2017, 23, 465-485. [CrossRef]

104. Ahmed, T.; Chandran, V.G.R.; Klobas, J. Specialized entrepreneurship education: Does it really matter? Fresh evidence from Pakistan. Int. J. Entrep. Behav. Res. 2017, 23, 4-19. [CrossRef]

105. Kassean, H.; Vanevenhoven, J.; Liguori, E.; Winkel, D.E. Entrepreneurship education: A need for reflection, real-world experience and action. Int. J. Entrep. Behav. Res. 2015, 21, 690-708. [CrossRef]

106. Bosma, N.; Hessels, J.; Schutjens, V.; Van Praag, M.; Verheul, I. Entrepreneurship and role models. J. Econ. Psychol. 2012, 33, 410-424. [CrossRef]

107. Stewart, W.H., Jr.; Roth, P.L. Risk propensity differences between entrepreneurs and managers: A meta-analytic review. J. Appl. Psychol. 2001, 86, 145-153. [CrossRef]

108. Zhao, H.; Seibert, S.E.; Lumpkin, G.T. The relationship of personality to entrepreneurial intentions and performance: A meta-analytic review. J. Manag. 2010, 36, 381-404. [CrossRef]

109. Audretsch, D.B.; Seitz, N.; Rouch, K.M. Tolerance and innovation: The role of institutional and social trust. Eurasian Bus. Rev. 2018, 8, 71-92. [CrossRef]

(C) 2020 by the authors. Licensee MDPI, Basel, Switzerland. This article is an open access article distributed under the terms and conditions of the Creative Commons Attribution (CC BY) license (http://creativecommons.org/licenses/by/4.0/). 